\title{
Participation Potential of Rural Women in Different Homestead Farm Activities
}

\author{
M. F. Khatun ${ }^{1}$, M. K. Hossain ${ }^{2}$, K. A. Hossain ${ }^{3}$ and M. M. Rahman ${ }^{1} *$ \\ ${ }^{1 \& 2}$ Deptartment of Agronomy \& Agricultural Extension, University of Rajshahi, Rajshahi-6205, \\ ${ }^{2}$ GUK-CLP, Gaibandha, ${ }^{3}$ Gram Unnayan Karma, Bogra-5800, Bangladesh \\ *Corresponding author and Email: mostafizur2001@yahoo.com
}

Received: 10 February 2014

Accepted: 14 June 2014

\begin{abstract}
The main purpose of the study was to determine the extent of participation of rural women in the cultivation of vegetables and fruit trees around the homestead areas. The study was conducted on married women of four selected villages of Raumari upazilla under Kurigram district. Data were collected from randomly selected 103 women by using pre-tested interview schedule during the month of May, 2013. In measuring the participation of rural women in homestead farm activities, cultivation of vegetables and fruit trees were considered as dependent variables. Each aspect consisted of 15 activities under three sub-headings. A three point Likert-type scale was used to measure each activity. The independent variables were measured by employing prevailing standard methods. Pearson's correlation coefficient ( $r$ ) was used in order to explore the relationships between the concerned variables. About 59 percent of the rural women had high participation in vegetables cultivation while only 10.68 percent of them had low participation in the cultivation of fruit trees. Among 15 statements of different aspects in relation to vegetables cultivation, tilling by spade was ranked first. In case of the cultivation of fruit trees, the highest proportion (46.60 percent) of rural women had medium participation and irrigation after planting was in the first position. Agriculture knowledge, attitude and innovativeness had positive relationship with the cultivation of vegetables. On the other hand, education, family income, cosmopoliteness behaviour and attitude had positive relationship with the cultivation of fruit trees.
\end{abstract}

Keywords: Participation, rural women, homestead, farm activities

\section{Introduction}

In Bangladesh, women hardly participate in agricultural activities outside their homes (Hossain, 2002; Abdullah and Zeidenstein, 1982). About half (49\%) of population of Bangladesh is women among them 45.6 percent are associated with the farming activities (Agricultural Diary, 2012). Women's agricultural activities are confined to homestead production and post-harvest operations. Women are active partners in farming and they undertake management along with men. There are certain unit operations in agriculture production where women dominate such as post harvest management and agro-processing. About 20 to $70 \%$ of the rural women are involved in agricultural production and post harvest activities. The agricultural activities in which the women play a very leading role are: transplantation, weeding, threshing, looking after cattle and other livestock (poultry, goat rearing, sheep rearing etc), collecting fodder, watering fruit plants, preparing and transporting manure and other inputs to the field. They also help in constructing and repairing of 
irrigation channels and storage facilities. Currently, women in Bangladesh have an anchoring role in the management of their families as well as equal participation in different economic activities like crop production, post harvest activities, poultry rearing, management of livestock and fisheries, pisciculture and miscellaneous income generating activities (Nessa et al., 2004). Especially in the rural areas resource poor households' women's participation in income generating activities in high because these households have higher number of family members in compare to lower number of capable male earning members (Al-Amin et al., 2004).

In Bangladesh, women's participation in economic activities in general and agriculture in particular has remained low. However, recent labor force survey conducted by the Bureau of Statistics (BBS, 2006) showed rapidly increasing participation of women in economic activities. With the absence of male members, women's role is changing from unpaid family worker to farm managers, a phenomenon termed as "feminization of agriculture" is visible. Only 3.85 percent of the female workers participated in crop farming in 2008, compared to 53 percent for men. Only about one (01) percent of the women participated in the agricultural labour market in 2000 and 2008. Women's participation in agricultural labor market remains insignificant at 1.07 percent of agricultural workers compared to 23 percent for male workers in 2008 (Source: http//:www. participation of rural women in farm activities). The situation now seems to be changing considerably due to the introduction of new technologies in agriculture and rural life. It is now well recognized that in any effort to raise production, employment and income in rural areas, both men and women should embrace agricultural and non agricultural activities at rural homes.

The role of women in the economic development of Bangladesh cannot be overlooked. Many reports show that women contribute more labour to agriculture than men do. Women are generally involved in crop related activities like composting, transplanting, sowing, weeding, harvesting, drying, homestead gardening, fruits and trees planting. They are also engaged in other non-farm activities like cooking, child care, washing, cleaning, tailoring, crafting etc. Women's involvement in homestead agriculture started from the time immemorial. They were pioneers in plant domestication and planned agriculture (Child, 1971).

In a prevalent subsistence agricultural economy and traditional society of Bangladesh, the role of Bangladesh women may be termed as domestic and hence they have to perform mostly such functions as can be performed within the homestead. Though their activities are not less important, but their contributions are conspicuous. They make these contributions by participating in pre and post-harvest operations and in various activities under homestead agriculture. These are in addition to their traditional role of housekeeping and child rearing (Ali, 1999). Many of these activities are not considered as the productive ones and hence not reflected in the national census (Sattar, 1979). As a result rural women enjoy a low profile in respect of contribution to the national economy. Assessment of the role of women in household activities particularly in homestead agriculture is therefore, important particularly for policy formulation and programs interventions for development of women. Considering the above view point the study was undertaken to: i) determine the extent of participation of rural women in the cultivation of homestead vegetables and fruits trees, and ii) explore the relationships between the selected characteristics of the rural women and their extent of participation in the cultivation of homestead vegetables and fruit trees.

\section{Methodology}

The locale of the study included four villages namely, Raumari Sadar, Datvanga, Tapurchar and Solmary villages of Raumari Sadar Upazila under Kurigram district. The total numbers of married women of those villages were 1030 of whom 103 women (10\%) were selected randomly for interviewed. Data were collected by 
using pre-tested interview schedule during the month of May, 2013. The independent-variables of this study were age, education, agricultural knowledge, farm size, family size, income of the family, cosmopoliteness, innovativeness and attitude. These were measured by employing prevailing standard methods.

Extent of participation of rural women in homestead farm activities was the dependent variable in this study. It was measured by selecting two major aspects of homestead farm activities- vegetables cultivation and fruit trees cultivation. In case of vegetable cultivation 5 activities were considered under each of the three sub-headings (Table 1): a) land preparation (land selection, tilling by spade, application for cow dung and manure, preparation of boundary and drain and weeding); b) transplanting of seedling (transplanting after uprooting, transplanting in rows, transplanting of seedling in the afternoon, application of mild irrigation after transplanting and shading arrangement after pruning); and c) irrigation \& water arrangement (drain operation, apply irrigation two-three times, timely irrigation, use watering can or other devices and draining out excess water) for measuring the extent of participation. Similarly, in respect of fruit trees cultivation 5 activities were considered under each of the three subheadings: a) planting of trees and fruits (line sowing, irrigation after planting, fencing or supporting, planting in afternoon and weeding time to time); b) irrigation (flood irrigation, split irrigation, irrigation before flowering, need based irrigation and irrigation after flowering); and c) management (loosening of soil surrounding the trees, weeding, pruning, pest management and fruit thinning).

A three point Likert-type scale was used to measure each activity. The scores of 0,1 , and 2 were assigned for no participation, occasional participation and regular participation, respectively. Participations scores in each aspect could range from 0 to 30,0 indicating no participation and 30 indicating regular participation. For clear understanding of comparative participation of rural women on 15 activities of each aspect, participation index (P1) was computed using the following formula:

$\mathrm{PI}=\left(\mathrm{P}_{\mathrm{np}} \times 0\right)+\left(\mathrm{P}_{\mathrm{op}} \times 1\right)+\left(\mathrm{P}_{\mathrm{rp}} \times 2\right)$

Where,

$\mathrm{P}_{\mathrm{np}}=$ Percentage of rural women with no participation

$\mathrm{P}_{\mathrm{op}}=$ Percentage of rural women with occasional participation

$\mathrm{P}_{\mathrm{rp}}=$ Percentage of rural women with regular participation

Participation index for any item of activity in 2 types of participation could range from 0-206 indicating no participation and regular participation, respectively.

\section{Results and Discussion}

\subsection{Participation of rural women in homestead vegetables cultivation}

Table 1 shows that homestead vegetables cultivation comprised of three major heads: (i) land preparation, (ii) transplanting of seedling, and (iii) irrigation and water management. Each of these headings included five sorts of participation (activities). Computed indices for participation in land preparation, transplanting of seedling, and irrigation and water management ranged from 42 to 116 (mean 88.8), 43 to 102 (mean 71.6) and 44 to 112 (mean 70.8) respectively.

Table 1 reveals that 'tilling by spade' (PI: 116) in land preparation, application of mild irrigation after transplanting' (PI: 102), in transplanting of seedling and timely irrigation (PI: 112) in irrigation and water management were the subheading wise highest ranked participation, respectively. Preparation of boundary and drain out (PI: 42), shading arrangement after pruning (PI: 43), and 'drain operation' (PI: 44) had the sub-heading wise lowest ranked participation index, respectively. However, participation indices (PI) in three out of five activities in land preparation exceeded 100 . 
Table 1. Head-wise participation of rural women in 15 activities related to homestead vegetables cultivation with indices and rank order

\begin{tabular}{|c|c|c|c|c|c|}
\hline \multirow[b]{2}{*}{ Activities } & \multicolumn{3}{|c|}{ Rural Women $(\mathrm{N}=103)$} & \multirow{2}{*}{$\begin{array}{l}\text { Participation } \\
\text { indices }\end{array}$} & \multirow{2}{*}{$\begin{array}{l}\text { Rank } \\
\text { order }\end{array}$} \\
\hline & $\begin{array}{l}\text { Regular } \\
\text { (2) }\end{array}$ & $\begin{array}{l}\text { Occasional } \\
\text { (1) }\end{array}$ & $\begin{array}{l}\text { Never } \\
(0)\end{array}$ & & \\
\hline \multicolumn{6}{|l|}{ (a) Land preparation } \\
\hline i. Land selection & $30 \times 2$ & 46 & 27 & 106 & 4 \\
\hline ii. Tilling by spade & $33 \times 2$ & 50 & 20 & 116 & 1 \\
\hline $\begin{array}{l}\text { iii. Application for cow dung } \\
\text { and manure } \\
\text { iv. Preparation of boundary }\end{array}$ & $31 \times 2$ & 48 & 24 & 110 & 3 \\
\hline and drain & $13 \times 2$ & 16 & 74 & 42 & 15 \\
\hline v. Weeding & $19 \times 2$ & 32 & 52 & 70 & 9 \\
\hline \multicolumn{6}{|l|}{ (b) Transplanting of Seedling } \\
\hline i. Transplanting after & $18 \times 2$ & 23 & 62 & 59 & 11 \\
\hline uprooting & $20 \times 2$ & 28 & 55 & 68 & 10 \\
\hline $\begin{array}{l}\text { ii. Transplanting in rows } \\
\text { iii. Transplanting of seedling }\end{array}$ & $28 \times 2$ & 30 & 45 & 86 & 6 \\
\hline $\begin{array}{l}\text { in the afternoon } \\
\text { iv. Application of mild }\end{array}$ & $19 \times 2$ & 64 & 20 & 102 & 5 \\
\hline $\begin{array}{l}\text { irrigation after } \\
\text { transplanting }\end{array}$ & $14 \times 2$ & 15 & 74 & 43 & 14 \\
\hline $\begin{array}{l}\text { v. Shading arrangement after } \\
\text { pruning }\end{array}$ & & & & & \\
\hline \multicolumn{6}{|c|}{ (c) Irrigation and water arrangement } \\
\hline i. Drain operation & $15 \times 2$ & 14 & 74 & 44 & 13 \\
\hline $\begin{array}{l}\text { ii. Apply irrigation two-three } \\
\text { times }\end{array}$ & $23 \times 2$ & 25 & 55 & 71 & 8 \\
\hline iii. Timely irrigation $\backslash$ & $24 \times 2$ & 64 & 15 & 112 & 2 \\
\hline $\begin{array}{l}\text { iv. Use watering can or other } \\
\text { devices }\end{array}$ & $30 \times 2$ & 20 & 53 & 80 & 7 \\
\hline v. Draining out excess water & $15 \times 2$ & 17 & 71 & 47 & 12 \\
\hline
\end{tabular}

\subsection{Comparative participation in fifteen activities}

Percentage distribution of rural women in each of the 15 activities related to homestead vegetables cultivation has been shown in Table 2 along with participation indices and rank order.

Computed participation indicates over 15 activities ranged from 42 to 116 with an average of 77.07. Table 2 reveals that the participation of rural women in respect of tilling by spade had the highest participation index (PI: 116), 'timely irrigation' was the second highest (PI: 112) and that for 'application of cow dung and manure' was the third highest (PI: 110). Participation in 'preparation of boundary and drain' had the lowest index (PI: 42). However, participation indices were more than 100 in five activities. Development activities especially with the rural women are sporadic and not based on sound planning. However, women constitute to about 50 percent of the population and remain at home as full time custodians undertaking many responsibilities like work at kitchen, child rearing and maintenance of homestead. 
Table 2. Comparative participation of rural women in 15 activities related to homestead vegetables cultivation with indices and rank order

\begin{tabular}{|c|c|c|c|c|c|}
\hline \multirow[b]{2}{*}{ Activities } & \multicolumn{3}{|c|}{ Rural women (N=103) } & \multirow{2}{*}{$\begin{array}{l}\text { Participation } \\
\text { Indices }\end{array}$} & \multirow{2}{*}{$\begin{array}{l}\text { Rank } \\
\text { order }\end{array}$} \\
\hline & Regular & Occasional & Never & & \\
\hline 1. Tilling by spade & 33 & 50 & 20 & 116 & 1 \\
\hline 2. Timely irrigation & 24 & 64 & 15 & 112 & 2 \\
\hline $\begin{array}{l}\text { 3. Application of cow dung } \\
\text { and manure }\end{array}$ & 31 & 48 & 24 & 110 & 3 \\
\hline 4. Land selection & 30 & 46 & 27 & 106 & 4 \\
\hline $\begin{array}{l}\text { 5. Application of mild } \\
\text { irrigation after trans } \\
\text { planting }\end{array}$ & 19 & 64 & 20 & 102 & 5 \\
\hline $\begin{array}{l}\text { 6. Transplanting of seeding in } \\
\text { the afternoon }\end{array}$ & 28 & 30 & 45 & 86 & 6 \\
\hline $\begin{array}{l}\text { 7. Use watering-can or other } \\
\text { device }\end{array}$ & 30 & 20 & 53 & 80 & 7 \\
\hline $\begin{array}{l}\text { 8. Apply irrigation two three } \\
\text { times }\end{array}$ & 23 & 25 & 55 & 71 & 8 \\
\hline 9. Weeding & 19 & 32 & 52 & 70 & 9 \\
\hline 10. Transplanting in rows & 20 & 28 & 55 & 68 & 10 \\
\hline $\begin{array}{l}\text { 11. Transplanting after } \\
\text { uprooting }\end{array}$ & 18 & 23 & 62 & 59 & 11 \\
\hline $\begin{array}{l}\text { 12. Draining out excess } \\
\text { water }\end{array}$ & 15 & 17 & 71 & 47 & 12 \\
\hline 13. Drain operation & 15 & 14 & 74 & 44 & 13 \\
\hline $\begin{array}{l}\text { 14. Shading arrangement } \\
\text { after uprooting }\end{array}$ & 14 & 15 & 74 & 43 & 14 \\
\hline $\begin{array}{l}\text { 15. Preparation of } \\
\text { boundary and drain }\end{array}$ & 13 & 16 & 74 & 42 & 15 \\
\hline
\end{tabular}

They were found to be very busy and active within the limited scope and enough in vegetables cultivation from their own idea for their own consumption though they have not been exposed to modern and improved practices. Participation indices reflected this situation. Effects were limited in the participation of some activities that could have been more improved and effective for modern cultivation. These indicate a great responsibility of the extension agencies at the grass roots to develop women as a new group of clients in extension.

\subsection{Overall participation of rural women in vegetables cultivation}

The participation score of rural women in homestead vegetables cultivation ranged from 0 to 30 , with an average of 16.48 and a standard deviation of 5.59. On the basis of the scores obtained in 15 activities, the rural women were classified into three levels, namely, low participation, medium participation and high participation (Table 3).

Table 3 reveals that 59.22 percent of women had medium participation, compared to 23.31 percent high and only 17.47 percent low participation category. Generally, rural women are busy at home. Rural social system encourages women to shoulder the responsibilities of all kinds of household activities including homestead 
farming activities. They participate 'the cultivation of crops around the homestead, especially vegetables. Their approach and attitude seem to be casual and traditional. They do it largely for domestic consumption. Only poor families send their homestead products to the local market for sale. Although the highest proportions of women participate in vegetables cultivation yet rest of them take it very carefully. The extension agencies must consider this.
Motivational work from extension agencies with the rural women would bring good success in vegetables cultivation and increase per capita income in the family. The women disseminate the success stories of their homestead farming (new improved practices) among the family members, neighbours and others, which inspire the fellow women to adopt homestead gardening. This would bring a new dimension in extension work in this country.

Table 3. Number and percentage distribution of rural women according to their participation in homestead vegetables cultivation

\begin{tabular}{lccccc}
\hline \multirow{2}{*}{ Category } & \multicolumn{2}{c}{$\begin{array}{c}\text { Rural Women } \\
(\mathrm{N}-103)\end{array}$} & \multirow{2}{*}{ Mean } & $\begin{array}{c}\text { Standard } \\
\text { Deviation }\end{array}$ \\
\cline { 2 - 3 } & Number & Percent & & \\
Low participation (3-11) & 18 & 17.47 & & \\
Medium participation (12-20) & 61 & 59.22 & 16.48 & 5.59 \\
High participation (20 \& above) & 24 & 23.31 & & \\
\hline Total & 103 & 100 & Max 28 & Min 3 \\
\hline
\end{tabular}

Table 4. Head-wise participation of rural women in 15 activities related to cultivating of fruit trees with indicates and rank order

\begin{tabular}{|c|c|c|c|c|c|}
\hline \multirow[b]{2}{*}{ Activities of operation } & \multicolumn{3}{|c|}{ Rural women $(\mathrm{N}=103)$} & \multirow[b]{2}{*}{$\begin{array}{l}\text { Participation } \\
\text { Indices }\end{array}$} & \multirow[b]{2}{*}{$\begin{array}{l}\text { Rank } \\
\text { order }\end{array}$} \\
\hline & $\begin{array}{c}\text { Regular } \\
\text { (2) }\end{array}$ & $\begin{array}{c}\text { Occasional } \\
\text { (1) }\end{array}$ & $\begin{array}{c}\text { Never } \\
(1)\end{array}$ & & \\
\hline \multicolumn{6}{|l|}{ (a) Planting of trees and fruits } \\
\hline i. Line sowing & $25 \times 2$ & 15 & 63 & 65 & 3 \\
\hline ii. Irrigation after planting & $36 \times 2$ & 16 & 51 & 88 & 1 \\
\hline iii. Fencing or supporting & $15 \times 2$ & 12 & 76 & 42 & 8 \\
\hline iv. Planting in afternoon & $25 \times 2$ & 35 & 43 & 85 & 2 \\
\hline v. Weeding time to time & $14 \times 2$ & 29 & 60 & 57 & 5 \\
\hline \multicolumn{6}{|l|}{ (b) Irrigation } \\
\hline i. Flood irrigation & $0 \times 2$ & 2 & 101 & 2 & 15 \\
\hline ii. Split irrigation & $3 \times 2$ & 8 & 92 & 14 & 13 \\
\hline iii. Irrigation before flowering & $6 \times 2$ & 40 & 57 & 52 & 6 \\
\hline iv. Need based irrigation & $2 \times 2$ & 46 & 55 & 50 & 7 \\
\hline v. Irrigation after flowering & $5 \times 2$ & 30 & 68 & 40 & 10 \\
\hline \multicolumn{6}{|l|}{ (c) Care and management } \\
\hline $\begin{array}{l}\text { i. Loosening of soil surrounding } \\
\text { the trees }\end{array}$ & $4 \times 2$ & 33 & 66 & 41 & 9 \\
\hline ii. Weeding & $7 \times 2$ & 46 & 50 & 60 & 4 \\
\hline iii. Pruning & $5 \times 2$ & 8 & 90 & 18 & 12 \\
\hline iv. Pest management & $2 \times 2$ & 25 & 76 & 29 & 11 \\
\hline v. Fruit thinning & $1 \times 2$ & 8 & 94 & 10 & 14 \\
\hline
\end{tabular}




\subsection{Participation of rural women in the cultivation of fruit trees}

Cultivation of fruit trees comprised of three major categories: (i) planting of trees and fruit trees, (ii) irrigation and (iii) care and management. Each of these categories included five activities (activities) of participation.

Participation scores in planting of trees and fruits, irrigation and care and management ranged from 42 to 88 (Mean 67.4), 2 to 52 (Mean 31.60 ) and 10 to 60 (mean 31.6), respectively. The head wise participation of rural women in 15 activities of fruit cultivation with their participation indices and rank order has been summarized in Table 4. Table 4 reveals that 'irrigation after planting' $(\mathrm{PI}=88)$ in planting of fruits trees, 'irrigation before flowering' $(\mathrm{PI}=52)$ in irrigation and 'weeding' (PI=60) in cultural operations and management had the highest index, respectively. On the other hands, 'fencing or supporting' ( $\mathrm{PI}=42)$, 'flood irrigation' $(\mathrm{PI}=2)$ and 'fruit thinning' $(\mathrm{PI}=10)$ had the lowest participation index, respectively. However, no item of participation indices related to the cultivation of fruit trees had exceeded 100 .

\subsection{Comparative participation in fifteen activities (fruit trees)}

Percentage distribution of rural women in each of the 15 activities related to the cultivation of fruit trees has been shown in Table 5 along with participation indices and rank order. Computed participation indices of 15 activities ranged from 2 to 88 with an average of 43.53 . Table 5 reveals that the participation of rural women in respect of 'irrigation after planting' was the highest $(\mathrm{PI}=88)$, 'planting in the afternoon' $(\mathrm{PI}=85)$, the second highest and that for 'line sowing' was the third highest $(\mathrm{PI}=65)$. Participation in 'flood irrigation', had the lowest index (PI=2). Irrigation after planting is very essential for seedlings which are usually practiced by women in homestead area.

Rural women used to prefer this type of work for the growth of plant by small watering can or other country devices in the evening time. Line sowing is another type of work done easily by women. Further care is to be taken to train the women in other type of works like irrigation, transplanting and application of fertilizer etc. which are more technical in nature.

Table 5. Comparative participation of rural women in 15 activities related to the cultivation of fruit trees with indices and rank order

\begin{tabular}{|c|c|c|c|c|c|}
\hline \multirow{2}{*}{ Activities of operation } & \multicolumn{3}{|c|}{ Rural women (N=103) } & \multirow{2}{*}{$\begin{array}{l}\text { Participation } \\
\text { Indices }\end{array}$} & \multirow{2}{*}{$\begin{array}{l}\text { Rank } \\
\text { order }\end{array}$} \\
\hline & Regular & Occasional & Never & & \\
\hline 1. Irrigation after planting & 36 & 16 & 51 & 88 & 1 \\
\hline 2. Planting in afternoon & 25 & 35 & 43 & 85 & 2 \\
\hline 3. Line sowing & 25 & 15 & 63 & 65 & 3 \\
\hline 4. Weeding & 7 & 46 & 50 & 60 & 4 \\
\hline 5. Weeding time to time & 14 & 29 & 60 & 57 & 5 \\
\hline 6. Need based irrigation & 6 & 40 & 57 & 52 & 6 \\
\hline $\begin{array}{l}\text { 7. Irrigation before } \\
\text { flowering }\end{array}$ & 2 & 46 & 55 & 50 & 7 \\
\hline 8. Fencing or supporting & 15 & 12 & 76 & 42 & 8 \\
\hline 9. Loosening of soil & 4 & 33 & 66 & 41 & 9 \\
\hline $\begin{array}{l}\text { 10. Irrigation after } \\
\text { flowering }\end{array}$ & 5 & 30 & 68 & 40 & 10 \\
\hline 11. Pest management & 2 & 25 & 76 & 29 & 11 \\
\hline 12. Pruning & 5 & 8 & 90 & 18 & 12 \\
\hline 13. Split irrigation & 3 & 8 & 92 & 14 & 13 \\
\hline 14. Fruit thinning & 1 & 8 & 94 & 10 & 14 \\
\hline 15. Flood irrigation & 0 & 2 & 101 & 2 & 15 \\
\hline
\end{tabular}


Table 6. Number and percentage, distribution of rural women according to their participation in the cultivation of fruit trees

\begin{tabular}{|c|c|c|c|c|}
\hline \multirow{2}{*}{ Category } & \multicolumn{2}{|c|}{ Rural Women $(\mathrm{N}=103)$} & \multirow{2}{*}{ Mean } & \multirow{2}{*}{$\begin{array}{l}\text { Standard } \\
\text { Deviation }\end{array}$} \\
\hline & Number & Percent & & \\
\hline \multirow{3}{*}{$\begin{array}{l}\text { Low participation (12-17) } \\
\text { Medium participation (18-23) } \\
\text { High participation ( } 23 \& \text { above) }\end{array}$} & 44 & 42.72 & 18.01 & 3.44 \\
\hline & 48 & 46.60 & \multirow{3}{*}{\multicolumn{2}{|c|}{ Max 29; Min 12}} \\
\hline & 11 & 10.68 & & \\
\hline Total & 103 & 100 & & \\
\hline
\end{tabular}

\subsection{Overall participation of rural women in} fruit trees cultivation

The participation score of rural women in the cultivation of fruit trees ranged from 12 to 29 , with an average of 18.01 and standard deviation 3.44. On the basis of the scores obtained is 15 activities, the rural women were classified into three levels, namely, low participation, medium participation and high participation which are presented in the Table 6 which shows that 46.60 percent of the women had medium participation, 42.72 percent had low participation and only 10.68 had percent high participation.

In general, women do not participate in field activities. In this study it was revealed that about 46.60 percent women had medium participation in fruit trees cultivation. Women play an important role in homestead forestry with the help of their family members. Women participation in fruit trees cultivation is mostly confined with intercultural operations and management practices. Extension agents now can play a vital role in growing interest among the women to plant fruit trees and can provide training on the issues for their active participation in future.

\subsection{Characteristics of the rural women}

Individual's behaviour in respect of certain affairs is very complex and at the same time very thrilling phenomenon. There are many interrelated and constituent attributes that characterize an individual and form an integral part in the development of his/her behaviour and personality. Besides individual's activity, decision and opinion in respect of certain activity is influenced by certain environmental variables. Such considerations led the researcher to select nine characteristics (Table 7) of the rural women for exploring their relationship with their participation. The highest proportion (51.46\%) of the rural women fell into young category compared to 44.66 percent in middle and only 3.88 percent old aged. In respect of education, more than $91.27 \%$ women were literate (in ranged from primary to secondary). It was revealed that literacy rate of the study area was found to be more than average national literacy rate. This is very much positive in respect of adoption of improved homestead farming practices. With regard to agricultural knowledge an overwhelming majority of women (92.23\%) had agricultural knowledge ranging from medium $(58.25 \%)$ and high $(33.98 \%)$.

In respect to farm size of rural women 45.63 percent fell into the marginal category, 44.66 percent into small and 9.71 percent into medium category. Most of the respondents $(67.96 \%)$ have small sized family compared to 28.16 percent large and 3.88 percent medium sized family. Annual income of the rural women was low $(58.25 \%)$ and very low $(22.33 \%)$. It is assumed that through homestead gardening they can increase their annual income. Majority $(51.45 \%)$ of the rural women fall into low cosmopoliteness category as compared to 29.13 percent in the medium category and 19.42 percent in very low cosmopoliteness category. Majority (37.86\%) of the rural women had medium innovativeness, where as 34.96 percent had high and only 27.18 percent had low innovativeness. In respect to attitude, more than 
half $(52.43 \%)$ fall into medium category compared to 40.78 percent low category and only 6.79 percent high category.

\subsection{Relationship between the characteristics of the rural women and their participation}

This section deals with the relationships of the nine selected characteristics of the rural women (independent variables) with their participation in homestead vegetable and fruit trees cultivation (dependent variables). Pearson's correlation coefficient was used to determine the relationships between the selected nine independent and two dependent variables (Table 8).

Agriculture knowledge, attitude and innovativeness had positive relationship with the participation in vegetables cultivation whereas other independent variables had no relationship. Agricultural knowledge is the most important factor in any agricultural practices.

Table 7. Salient features of selected rural women (103)

\begin{tabular}{|c|c|c|c|c|c|}
\hline \multirow{2}{*}{ Character } & \multirow{2}{*}{ Category } & \multicolumn{2}{|c|}{ Rural Women } & \multirow{2}{*}{ Mean } & \multirow{2}{*}{$\begin{array}{l}\text { Standard } \\
\text { Deviation }\end{array}$} \\
\hline & & Number & Percent & & \\
\hline \multirow{3}{*}{ Age } & Young (up to 35) & 53 & 51.46 & \multirow{3}{*}{35.68} & \multirow{3}{*}{9.39} \\
\hline & Middle age (36-50) & 46 & 44.66 & & \\
\hline & Old (50 to above) & 4 & 3.88 & & \\
\hline \multirow{5}{*}{ Education } & Illiterate $(0)$ & 3 & 2.91 & \multirow{5}{*}{6.78} & \multirow{5}{*}{3.10} \\
\hline & Can sign only $(0.5)$ & 6 & 5.82 & & \\
\hline & Primary $(1-5)$ & 23 & 22.33 & & \\
\hline & Mid school (6-9) & 56 & 54.38 & & \\
\hline & SSC \& above ( $10 \&$ above $)$ & 15 & 14.56 & & \\
\hline \multirow{3}{*}{$\begin{array}{l}\text { Agricultural } \\
\text { knowledge }\end{array}$} & Low (up to 14) & 8 & 7.77 & \multirow{3}{*}{20.58} & \multirow{3}{*}{3.85} \\
\hline & Medium (14.5-22) & 60 & 58.25 & & \\
\hline & High (22.5 and above) & 35 & 33.98 & & \\
\hline \multirow{3}{*}{ Farm size } & Marginal (0.02 to $0.20 \mathrm{ha})$ & 47 & 45.63 & \multirow{3}{*}{0.38} & \multirow{3}{*}{0.49} \\
\hline & Small (0.21 to $1.0 \mathrm{ha})$ & 46 & 44.66 & & \\
\hline & Medium (1.1 to 3 ha) & 10 & 9.71 & & \\
\hline \multirow{3}{*}{ Family size } & Small family (up to 5) & 70 & 67.96 & \multirow{3}{*}{5.11} & \multirow{3}{*}{2.17} \\
\hline & Medium family (6 to 8 ) & 29 & 28.16 & & \\
\hline & Large family (above 8) & 4 & 3.88 & & \\
\hline \multirow{5}{*}{ Annual income } & Very low income (14-59) & 23 & 22.33 & \multirow{5}{*}{89.25} & \multirow{5}{*}{4.71} \\
\hline & Low income $(60-100)$ & 60 & 58.25 & & \\
\hline & Medium income (101-150) & 10 & 9.72 & & \\
\hline & High income (151-200) & 7 & 6.79 & & \\
\hline & Very high income $(>200)$ & 3 & 2.91 & & \\
\hline \multirow{3}{*}{ Cosmopoliteness } & Very low cosmopoliteness (1-2) & 20 & 19.42 & \multirow{3}{*}{3.75} & \multirow{3}{*}{1.49} \\
\hline & Low cosmopoliteness (3-4) & 53 & 57.45 & & \\
\hline & Medium cosmopoliteness (5-7) & 30 & 29.13 & & \\
\hline \multirow{3}{*}{ Innovativeness } & Low innovativeness (4-9) & 28 & 27.18 & \multirow{3}{*}{12.39} & \multirow{3}{*}{3.33} \\
\hline & Medium innovativeness (10-14) & 39 & 37.86 & & \\
\hline & High innovativeness (above 15) & 36 & 34.96 & & \\
\hline \multirow{3}{*}{ Attitude } & Very low attitude (4-6) & 42 & 40.78 & & \\
\hline & Low attitude (7-9) & 54 & 52.43 & 7.10 & 1.55 \\
\hline & Medium attitude $(>9)$ & 7 & 6.79 & & \\
\hline
\end{tabular}


Table 8. Correlation between independent and dependent variables $(n=103)$

\begin{tabular}{lcc}
\hline & \multicolumn{2}{c}{ r-value } \\
\cline { 2 - 3 } Independent variables & $\begin{array}{c}\text { Participation in homestead } \\
\text { vegetables cultivation }\end{array}$ & $\begin{array}{c}\text { Participation in cultivation } \\
\text { of fruit tress }\end{array}$ \\
\hline 1. Age & $0.095 \mathrm{NS}$ & $-0.011 \mathrm{NS}$ \\
2. Education & $-0.034 \mathrm{NS}$ & $0.317^{* *}$ \\
3. Agricultural knowledge & $0.200^{*}$ & $0.193 \mathrm{NS}$ \\
4. Farm size & $0.100 \mathrm{NS}$ & $0.121 \mathrm{NS}$ \\
5. Family size & $0.050 \mathrm{NS}$ & $0.076 \mathrm{NS}$ \\
6. Family income & $-0.072 \mathrm{NS}$ & $0.270^{* * *}$ \\
7. Cosmopoliteness & $0.152 \mathrm{NS}$ & $0.253^{* *}$ \\
8. Attitude & $0.481^{* *}$ & $0.647^{* *}$ \\
9. Innovativeness & $0.210^{*}$ & $0.184 \mathrm{NS}$ \\
\hline
\end{tabular}

$\mathrm{NS}=$ Non significant,$*=$ Correlation is significant at 0.05 level of probability,

$* *=$ Correlation is significant at 0.01 level of probability

If a woman has highly agricultural knowledge, she can easily use improved technology in vegetable production. Attitude implies an individual's predisposition to respond in a characteristic way to some stimuli in her social environment. Innovators are active information seekers about the new ideas. They have a high degree of mass media exposure and their interpersonal networks extend over a wide area, reaching outside their local system (Rogers, 1995). On the other hand, education, family income, cosmopoliteness and attitude had positive relationship with the cultivation of fruit trees and other attributes had no relationship. Education helps the women to broaden their outlook and expand their mental horizon by helping them to develop favorable readiness in their mind. As a result a woman is likely to be more receptive to the modern facts and ideas. Higher annual income of the respondents allows them to invest more in farming operations. Rogers and Svenning (1969) stated that a peasant must have contact with outside world in some manner before he becomes a cosmopolite. Physical transport facilities such as roads and public bus service provide the possibility for actual peasant contact with the world outside his village. Individuals who are cosmopolite frequently come in contact with new people, new things and new ideas. Cosmopoliteness thus brings a change in the mental makeup of the people and makes them more receptive for new ideas.

\section{Conclusions}

Despite the poor socio-economic status and overall demand, the rural women of Kurigram district actively participated in various activities in relation to vegetables and fruit trees cultivation in their homestead area. But it was not at satisfactory level. The situation probably was due to lack of awareness, knowledge and attitude in relation to homestead farming activities and basic education. In respect of vegetables cultivation, computed indices revealed that the participation of rural women in tilling by spade was the highest. Application of timely irrigation was the second highest and participation in application of cow dung and manure had the lowest index. In respect of the participation of rural women in the cultivation of fruit trees, it was found that irrigation after planting in trees, irrigation before flowering and weeding and management had the highest index, respectively. Therefore, government and nongovernment development initiatives should take necessary steps for improving these situations. 


\section{References}

Abdullah, T. and Zeidenstein, S. 1982. Rural Women Development Paper Presented at the Seminar on the Role of Women in Socio-Economic Development in Bangladesh. Bangladesh Economic Development in Bangladesh, Dhaka: 9-10 May.

Agricultural Diary. 2012. Agricultural Information Services. Department of Agricultural Extension, Ministry of Agriculture, Government of the Peoples Republic of Bangladesh. Dhaka, Bangladesh.

Al-Amin, S., Miah, M. A. M. and Chowdhury, A. H. 2004. Role of Rural Women in the Improvement of Livelihoods of Resource Poor Households. Bangladesh Journal of Extension Education, $16 \quad$ (Special Issue):25-33.

Ali, M. A. 1999. Opinion of Unemployed Rural Youth on Self-Employment by Undertaking Selected Income-Generating Activities in Fulbaria Thana under Mymensingh District. M.S. (Ag. Ext. Ed.) Thesis, Department of Agricultural Extension Education, Bangladesh Agricultural University, Mymensingh.

BBS. 2006. Year Book of Agricultural Statistics of Bangladesh. Bangladesh Bureau of Statistics, Statistics Division, Ministry of
Planning, Government of the People's Republic of Bangladesh. Dhaka, Bangladesh.

Child, G. V. 1971. Rural Development Participation: Concept and Measures for Project Design, Implementation and Education, Ithaca, New York University.

Hossain, M. S. 2002. Resource Poor Farmers' Problem Confrontation in using Manures Towards Integrated Plant Nutrient System (IPNS). M.S. (Ag. Ext. Ed.) Thesis. Department of Agricultural Extension Education, Bangladesh Agricultural University, Mymensingh.

Nessa, J., Hossain, S. M. A and Halim, A. 2004. Role of Women in Livelihoods Improvement through Integration in Homestead Production. Bangladesh Journal of Extension Education, 16 (Special Issue):103-107.

Rogers, E. M. 1995. Diffusion of innovation. $4^{\text {th }}$ edition, The Free Press, New York, USA.

Rogers, E. M. and Svenning, L. 1969. Modernization Among Peasant: The Impact of Communication. Holt, Rinehart and Winston, Inc. New York, USA.

Sattar, E. 1979. Demographic Feature of Bangladesh with a Reference to the Women and Children in Situation of Women in Bangladesh. Women for Women, Dhaka. 